Canadian Studies in Population, Vol. 30(2), 2003, pp. 355-388

\title{
Trends in the Occupational and Earnings Attainments of Women Immigrants to Canada, 1971-1996
}

\author{
Richard A. Wanner \\ Michelle Ambrose \\ Department of Sociology \\ University of Calgary \\ Calgary, Alberta
}

\begin{abstract}
This study examines the extent to which immigrant women arriving in Canada between the 1960s and the early 1990s were able to attain occupations and earnings equivalent to those of Canadian-born women using a data file created by merging public-use microdata files from Censuses of Canada between 1971 and 1996. We study both changes in country of birth effects on the earnings and occupational status of women aged 25 to 29 immigrating prior to each of the five census years and the experience of successive female immigrant cohorts as they age to determine the extent to which the effects of birthplace on occupational status and earnings change over their careers. In both cases we find a considerable advantage associated with being educated in Canada compared to being educated abroad. For those visible minority immigrants just beginning their careers in Canada, we could find no evidence that more recent cohorts have lower attainments than earlier cohorts, though this was true for some European groups. In our analysis of aging cohorts we find evidence of a tendency for immigrant earnings to converge with those of the Canadian born and for that tendency to be stronger in more recent cohorts.
\end{abstract}

Key Words: immigration, women, occupation, earnings 
Richard A. Wanner and Michelle Ambrose

\section{Résumé}

Cette étude examine à quel point les femmes immigrantes arrivant au Canada entre les années 60 et le début des années 90 étaient capables d’obtenir les emplois et les traitements équivalents aux ceux des femmes canadiens de souche, en utilisant un fichier de données créé par une fusion des micro-fichiers de données en provenance des Recensements du Canada pris entre 1971 et 1996. Nous étudions, d'un côté, des changements des effets du lieu de naissance sur le statut professionnel et de revenu des femmes entre l'âge 25 et 29 immigrant avant chaque période de recensement quinquennale et, d'autre côté, l'expérience des cohorts immigrants féminins successifs alors qu’elles vieillissent, afin de découvrir l'incidence du lieu de naissance sur le statut professionnel et les gains et comment cela a changé à travers leurs carrières. Dans les deux cas, nous trouvons l'avantage considérable lié avec l'éducation obtenue au Canada par rapport à l'éducation obtenue à l'étranger. Pour les immigrants minoritaires visibles au début de leurs carrières, nous n’avons pu trouver aucune évidence que les cohorts plus récents ont les gains plus bas que les cohorts plus tôt, quoiqu'il ceci soit vrai pour quelques groupes européans. Dans notre analyse des cohorts âgés, nous trouvons de l'évidence d'une tendance pour les gains immigrants à converger avec ceux des canadiens de souche, et de l'évidence, dans les cohorts plus récents, pour cette tendance à être plus forte.

Mots clés: l'immigration, les femmes, la profession, les gains professionnels

\section{Introduction}

Consistent with Canada's role as one of the major immigrant receiving countries of the world, a great deal of recent research has been devoted to documenting and understanding differences in the earnings and occupational attainments of various immigrant ethnic groups compared to the Canadian born (Boyd 1984; DeSilva 1992; Green 1999; Pendakur and Pendakur 1998; Pendakur 2000) as well as differences in returns to education and labour market experience ( $\mathrm{Li}$ 2001; Wanner 1998). This research generally finds that members of visible minority groups both earn less and have lower returns to human capital than the Canadian born and those immigrating from most parts of Europe, although much of it focuses exclusively on men to the neglect of woman, who constitute a large and increasing proportion of the labour force. Such findings have taken on 
greater importance as the stream of immigrants to Canada has shifted from Europe and the United States to Asia, Africa, Latin America, and the Caribbean since the 1960s. As well, since the 1970s larger proportions of immigrants have arrived in the family and refugee classes, and hence unscreened for skills compatible with the Canadian labour market (Wright and Maxim 1993), though this has by no means been a consistent trend since the early 1980s. Policy makers have become alarmed enough by the problems posed by integrating less skilled immigrants that they have recently yet again increased the skill requirements for independent immigrants.

Given that much of it is cross-sectional in design or uses older data ${ }^{1}$, the existing research does not generally determine whether or not the increased flow of immigrants from less developed countries admitted without screening for skills has in fact altered the ability of immigrants to Canada to integrate into the labour market, with a few notable exceptions. Research using Citizenship and Immigration Canada's Longitudinal Immigration Data Base and cross-tabular or graphic methods (Ruddick 1999) confirmed the policy makers' assumption that recent immigrants are not doing as well, particularly those entering in the family and refugee classes. Using data from the 1971, 1981, and 1986 censuses of Canada, Bloom et al. (1995) determined that more recent male and female immigrant cohorts have had greater difficulty "assimilating" in the Canadian labour market, defined in terms of catching up to the wages of the Canadian born. This was particularly true of immigrant men from Asia, Africa, and Latin America. Wanner (2003b) found that among male immigrants arriving prior to 1971, those from less developed regions and those from more developed countries if they obtained their highest level of education before coming to Canada had greater difficulty attaining higher status occupations compared to the Canadian born. More specifically, he found that the odds of Asian and Latin American immigrants educated abroad of attaining higher ranking occupations declined over time as their representation in the immigrant stream grew, consistent with the quality of skills and selection hypotheses advanced by Borjas $(1987 ; 1993 ; 1994)$. Beyond using the most recently available Canadian census data, this paper does two things to advance this line of research. By utilizing data from five censuses since 1971, it studies both labour market attainment upon arrival and changes in attainment over time both in terms of earnings and occupation, and it focuses on women, whose experience has not always been well represented.

\section{Women Immigrants to Canada}

Why concentrate on women? Boyd (1984)indicates that women immigrants face entry into a labour market that not only penalizes their immigrant status, but also 
is gender segregated in ways that provide access to jobs with lower wages, less security, and less opportunity for advancement than those occupied by men. She also points out that, with the demands placed on women for work in the home, employment outside the home represents a double burden that may prevent many immigrant women from learning the language of the host society, and hence condemning them to ethnic employment niches. Devoting this analysis to women without the diversion of constantly comparing their labour market experiences to those of men permits us to more fully understand the extent to which immigrant women have been able to attain the same levels of earnings and occupational status as Canadian-born women and how this may have changed from the 1960s to the 1990s. It also permits us to specify models that include variables relevant to women's attainments, such as number of children, as well as a correction for the sample selection bias introduced by variations in their labour market participation patterns.

Traditionally more men than women have migrated. This was especially true during the late 1800s and early 1900s when demand was high for manual labourers (Kelley and Trebilcock 1998). Despite the Canadian government launching a campaign to recruit European women to Canada, during the period 1870 to 1930 , as domestic workers and as wives for immigrant men (Cunningham 1995), immigrant men still outnumbered immigrant women. This gender gap did narrow over the years and by 1981 the number of immigrant women in Canada's immigrant population outnumbered immigrant men, a consequence, perhaps of changes to immigration policy in the late 1970s encouraging family reunification (Boyd 1992b). During the decade between 1981 and 1991, 304,282 women entered Canada under the family reunification program as opposed to 219,418 men (Wanner 2003b). Women, however, are more likely to enter as the spouse of the principal applicant as opposed to being the principal applicant herself. As well, women are less likely to enter Canada under the refugee class. Of the women accepted into Canada between 1981 and 1991, 43 percent of them were accepted under classes other than those with humanitarian criteria.

Given that immigrant women arriving in Canada are largely accepted under the family class (Boyd 1992b) or as dependents in the independent class, their ethnic distribution in Canada reflects that of their male counterparts. Those who entered before 1951 were for the most part British or American. More specifically, prior to 1951 two in five immigrant women were born in the United Kingdom (Sorenson 1995). Since the removal of national origin as a criterion for selecting immigrants and the introduction of the point system in 1967, the proportion of immigrants from Asia, Africa, Latin America and the Caribbean has risen steadily so that by the early 1990s immigrants from Europe made up just over 22 percent of the total arriving in Canada (Li 2003). 
As mentioned earlier, the modification in the ethnic distribution, which has occurred among Canada's immigrants over the past half century, has had far reaching consequences for the occupational stratification of male immigrants (Wanner, 2003b). The same holds true for immigrant women and is perhaps exacerbated by gender. Gender stratification in countries of origin is frequently translated into lower educational and employment - related training as women's roles within the family shape and constrain employment (Boyd 1992b).

Because of the shift of immigrants from the traditional source countries, today's immigrants are less likely to be fluent in either of the host languages due to greater linguistic distance (Boyd 1992a). They are more likely to be members of a visible minority group possibly facing discrimination, are more likely to gain entry under humanitarian considerations and are therefore likely to be less experienced in the labour market when compared to those accepted under the point system (Prefontaine and Benson 1999). These shifts in immigrant flows as a result of policy changes between 1953 and 1978 are strong reasons to expect changes in the labour market performance of recent Canadian immigrants, as is the shift based on the 1978 legislation from predominantly independent immigrants to a larger proportion of family class immigrants and particularly refugees. Green and Green (1999) point out that under provisions of that Act family members and refugees were given the highest processing priority and a commitment was made to admit a given number of refugees each year rather than only in the face of an international emergency.

\section{Theoretical Background}

While a great deal of theorizing has been devoted to understanding why members of minority ethnic or racial groups should have lower earnings, inferior occupations, or fewer opportunities to obtain a job in the first place, considerably less attention has been devoted to explaining changes in the opportunity structure. The most consistently cited mechanism producing lower attainments for members of visible minority groups is prejudicial attitudes leading to discriminatory behaviour. Sociologists have typically assumed that, in the labour market, ethnic or racial prejudice on the part of employers, and sometimes workers, has produced discriminatory behaviour that restricts the opportunities of members of minority groups that are its object (Evans and Kelley 1991). Such discrimination might take the form of refusing to hire members of the minority group or, once hired, paying them wages lower than the prevailing wage or refusing to promote them regardless of training, skills, or experience. The former constitutes exclusionary discrimination, while the latter two are defined as economic discrimination, measured in terms of the extent to 
which the returns to human capital endowments depart from returns among members of the majority group. Since the degree of prejudice is assumed to be a function of social and cultural distance, the theory would predict that economic discrimination would increase as a function of distance, but decrease to the extent that the level of prejudice in the majority population declines. One would thus expect non-European immigrants to be less likely to attain higher-ranking occupations, though the extent to which this is true should decline as prejudice is reduced with the introduction of employment equity and anti-bias legislation and shifting values.

A more sophisticated variant of prejudice/discrimination theory is queuing theory (Hodge 1973; Lieberson 1980; Thurow 1975). The main assumption of this theory is that potential employees are arranged in a queue on the basis of their desirability to employers. However, given the difficulty associated with assessing desirability, employers are inclined to rate applicants on the basis of observable characteristics they believe to be associated with productivity, such as race, ethnicity, immigration status, or gender. They then hire for the best jobs workers whose ancestry they rate as most desirable, as long as the supply of such workers lasts. At that point they will consider hiring workers with less desirable ethnic affiliations in order of their desirability. Although straightforward application of this model is complicated by the existence of employers who are members of ethnic minorities and the job preferences exhibited by members of some ethnic groups, in general the theory predicts that the average occupational level of members of an ethnic group will depend upon the proportion of workers ranked higher in the queue by employers. In contrast to prejudice/discrimination theory, queuing theory would predict that as the proportionate share of an ethnic minority rises in the population, its average occupational level should also rise, as employers have fewer options to employ members of preferred groups. One feature of the analysis presented here that flows from the assumptions of queuing theory is our choice to model separately the attainments of those educated abroad from those educated at least in part in Canada. Presumably the latter will be ranked much higher in the labour queue, since their credentials are more likely to be known to employers, and hence they should be more likely to attract jobs and earnings similar to those of the Canadian born. Indeed, some Canadian research has confirmed the importance of studying these two groups separately (Li 2001; Wanner 1998).

Economists subscribing to neoclassical theory (Becker 1971) doubt that discrimination can exist for long in market economies, since employers have a strong incentive to eliminate ethnic discrimination if its practice reduces profits. Given a free and competitive labour market and equivalent productivity, they believe that cheaper immigrant labour will inevitably be hired in preference to more expensive native-born labour, because the practice boosts profitability. 
Employers who insist on discriminating against immigrants will pay the price in higher costs and lower profits. The "rational" employer, subject to competition with firms employing cheaper immigrant labour, will overcome his or her prejudicial attitudes and also hire immigrants, bringing the market back into equilibrium. The theory is really designed to apply to wage rates, but certainly has implications for occupational attainment: although recent immigrants initially may be allocated to lower status occupations, as they acquire human capital in the host country their occupational distribution should approximate that of the native born. Specifically, we should expect to see the effect of place of birth on earnings and occupational status decline as an immigrant cohort acquires more experience in the host country.

Two additional explanations of ethnic inequality are inspired by the work of Borjas in the U.S. $(1987 ; 1993 ; 1994)$. He points out that immigrants are not randomly selected members of the source countries. Instead the distribution of skills among them depends on the economic situation in the source country and the immigration policies of the host country. In addition, for a given level of education and experience, immigrants originating in more developed countries are assumed to be more skilled and, as a consequence, more successful in the host country's labour market than immigrants from less developed countries. Given that the source country distribution of immigrants to Canada has shifted dramatically to favour immigrants from less developed countries and the proportion of immigrants that come in under the point system designed to select those who best match Canadian labour market conditions has fallen since the late 1970s (Wright and Maxim 1993), we should expect the average returns to human capital among immigrants to fall and the probability that they will be allocated to less desirable jobs with lower earnings will rise.

None of the theories reviewed are gendered in the sense that they would predict differences between men and women in the attainments of different immigrant cohorts. However, to the extent that immigrant women are coming to Canada increasingly from countries which are more culturally and linguistically distant from Canada's European roots and in which women are accorded fewer opportunities to acquire education and in the labour market generally, they are more likely to find employment in ethnically or linguistically bounded labour markets and hence encounter difficulty assimilating economically. Thus the principles of Borjas's selection and quality of skills hypotheses would seem to apply particularly to women and more particularly to those lacking Canadian credentials. 
Richard A. Wanner and Michelle Ambrose

\section{Data, Design, and Methods}

The Data. The analysis presented here is based on data from five Census of Canada public-use files, those for 1971, 1981, 1986, 1991, and 1996. All five are based on random samples from respective full censuses, though the sample is 1 percent of the total in 1971, 2 percent in 1981, and 3 percent from 1986 to 1996. Although the 1991 and 1996 censuses contain an extensive assortment of variables that might be used in modeling status attainment, previous censuses contain many fewer variables. However, a reasonable common model controlling for several crucial human capital resources and social characteristics across censuses can be estimated from all five census files. ${ }^{2}$ The analysis presented here is limited to women in the labour force at the time of the census and employed by others.

Design. The objective of the analysis is to study both the earnings and occupational attainment of cohorts arriving in Canada before each of the census years (except 1996) over time to determine the extent to which the immigrant earnings and occupations approaches that of the Canadian born over the course of the career as well as the attainment of successive cohorts arriving prior to each census year to determine the impact of the shifting source-country distribution of immigrants on their occupational attainment in Canada. To this end, we created two separate analysis files from the three census sources. The first file includes respondents age 25 to 29 in each of the census years who immigrated prior to those years. The 25-29 age group was chosen as the focus for this analysis for several reasons. By age 25 , most persons have completed their schooling and have entered the labour force, though most are likely still employed in an entry-level job. This makes the comparison of immigrants to the native born "fairer" in the sense that both groups are encountering the problems associated with recent labour force attachment. Although it is not necessarily true for family class immigrants, independent immigrants tend to be overwhelmingly under age 35 when they arrive, so this narrow age band captures a majority of immigrants as they make the transition to employment.

For the second analysis file, we selected respondents who arrived prior to each census, but were then "observed" as they age in a subsequent census. This file includes both the Canadian born, as a benchmark, and immigrants who arrived in Canada prior to each of the censuses from 1971 to 1991. The main problem with attempting to assess age effects with a sequence of cross sections rather than a panel design is that such effects may be biased by changes in the composition of a particular cohort across censuses, particularly as a result of return migration to the origin country or further migration to another destination, particularly the U.S. (Borjas, 1994). However, a design that merges cross- 
sections in this way is superior to using age cohorts from a single cross section, since it separates an immigrant's entry cohort from the time elapsed since she arrived (Bloom, Grenier, and Gunderson 1995).

This design is illustrated schematically in Figure 1, where the shaded diagonals indicate the cohorts to be studied. It is evident there that the first analysis file (the "sequence of cohorts" file), represented by the top row in the figure, controls for age permitting the study of how shifts in source-country distribution, the relative size of immigrant cohorts, and the effects of changes to immigration policy over two decades may have influenced the attainments of immigrants vis-à-vis the Canadian born. The issue addressed in that analysis will be whether the earnings and occupational attainments of immigrants from different regions of the world have diverged or converged with those of the Canadian born over the 25 -year period covered by the data. The second analysis file (the "aging cohorts" file) permits the assessment of both age effects on earnings and occupational attainment controlling for cohort effects and cohort effects controlling for age. Our primary focus in that analysis is on convergence of immigrant attainments with those of the Canadian-born as their careers unfold, i.e. do immigrants catch up or lag behind as their Canadian experience increases.

Measures. A serious defect in using census public use files is that, for purposes of confidentiality, Statistics Canada routinely provides highly collapsed versions of many key variables, particularly occupation. Not only that, but the Standard Occupational Classification (SOC) in use until the 1991 census was a peculiar amalgam of an occupational classification and an industry classification. Instead of classifying occupations in a hierarchical fashion according to skill, as does the new National Occupational Classification, the SOC frequently aggregates occupations according to function (e.g. transport equipment operating occupations) or industry (e.g. occupations in medicine and health). On the positive side, Statistics Canada has provided the SOC categories in all the census public use files used in this analysis. Our dependent variable in the occupational models is a dichotomy coded 1 if the respondent's occupation was either professional or managerial, 0 otherwise. ${ }^{3}$ In this way these models permit us to assess the odds of being in a higher-ranking occupation, although these are extremely gross categories encompassing specific occupations with a wide range on any scale of occupational status. The second dependent variable, the natural logarithm of wages, is considerably less problematic, since all five of the public use microdata files include wages to the nearest dollar. Since we ascertain earnings for years prior to each census between 1971 and 1996, they are adjusted for changes in the consumer price index and expressed in 1996 dollars. To avoid numerical problems, we eliminate cases reporting zero earnings. 
Figure 1

Census Years in Which Entry Cohorts

were First Observed and Age Cohorts Used in Analysis

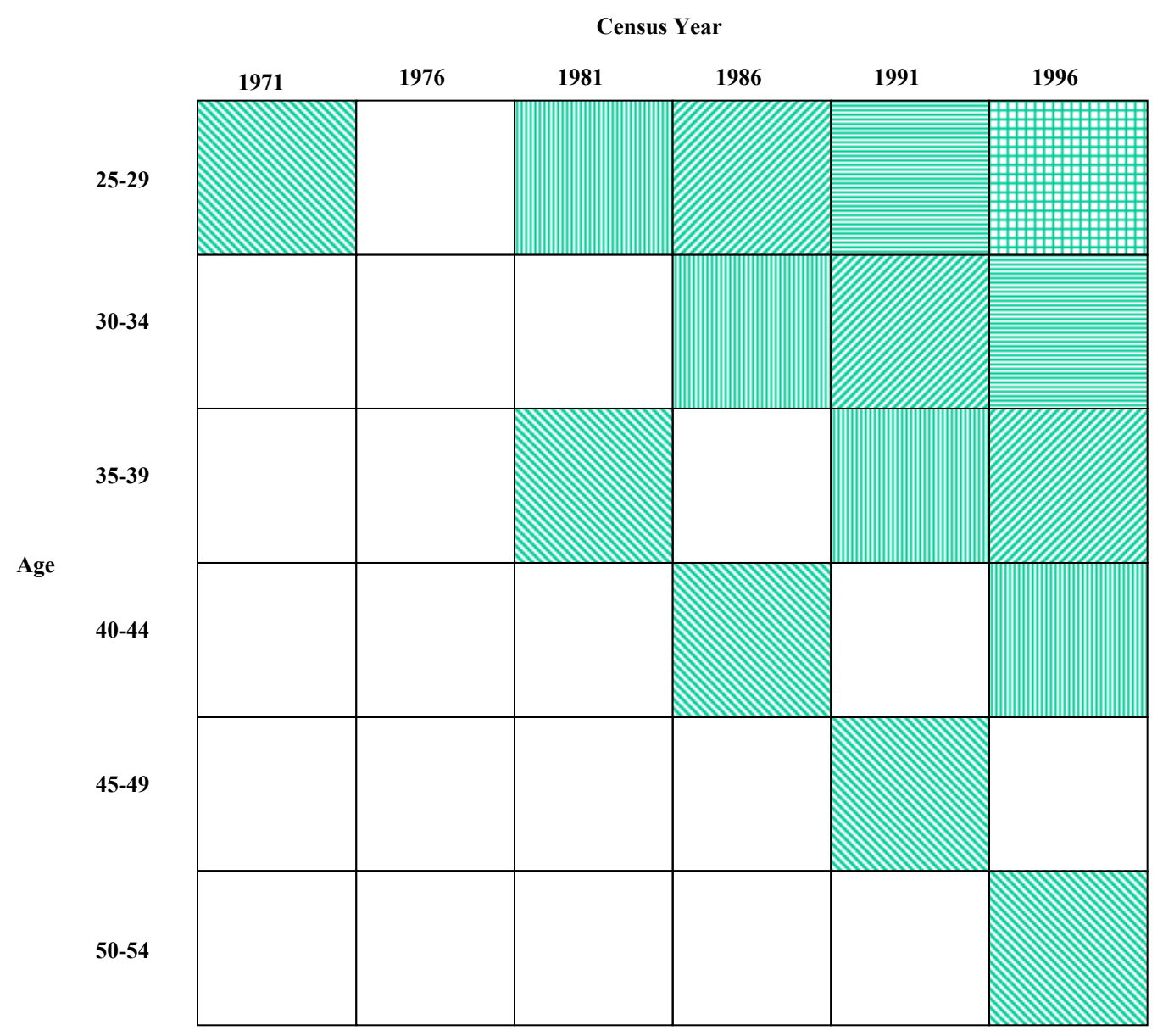


Like the occupational measure, the measure of country of origin used here is constrained by the collapsed variables available in the census public use files, particularly that in the 1971 file. The categories we use do not necessarily refer directly to country of origin, but also have built into them certain advantages or disadvantages carried by immigrants to Canada. For example, it would not be realistic to classify all immigrants from South Africa into a single category, since whites and blacks, particularly until recently, have functioned in separate economic and social circumstances. Instead, we assigned whites to a category including all white immigrants from Anglophone or Francophone countries, and blacks to a category including nonwhite immigrants from Africa and the Caribbean. Immigrants from counties in which one of Canada's official languages is the mother tongue have an obvious advantage in the Canadian labour market with the "language capital" they bring with them. Therefore, we assign white immigrants from Anglophone or Francophone countries to a separate category. The other categories are more straightforward, classifying immigrants by their source region: Northwestern Europe, Southern Europe, Eastern Europe, Asia, and Latin America.

Models. The analysis reported here is based on OLS regressions for the earnings models and logistic regressions for the occupation models. The occupation models include as independent variables a set of dummy variables for place of birth (Canada is the reference category), as well as measures of years of schooling, language proficiency, marital status, number of children and size of place of residence in Canada. The earnings models add controls for weeks worked and a dummy variable coded 1 if the respondent worked mainly parttime. All these measures are described in more detail in the Appendix Table. Since our intention is to estimate trends in the earnings and occupational attainments of immigrants compared to the Canadian born, the models also include linear versions of year of entry cohort and/or age, as appropriate, along with their interactions with place of origin. The full model for the "sequence of cohorts" analysis that controls for age is:

$$
Y_{i}=\alpha+\sum \beta X_{i}+\sum \beta P_{j}+\beta C_{i}+\sum \beta\left(P_{j} C_{i}\right)+\varepsilon_{i}
$$

where $Y_{i}$ is either $\log$ earnings or a dichotomous variable coded 1 if the respondent is in a professional or managerial occupation, the $X_{i}$ are the socioeconomic characteristics, the $P_{j}$ are the place of birth dummy variables, $C_{i}$ is a metric cohort variable coded 0 for 1971, 10 for 1981, 15 for 1986, and so 
on, and $P_{j} C_{i}$ is an interaction that captures linear cohort trends in place of birth effects. The full model for the "aging cohorts" analysis is similar:

$$
\begin{aligned}
& Y_{i}=\alpha+\sum \beta X_{i}+\sum \beta P_{j}+\beta C_{i}+\beta A_{i}+ \\
& \sum \beta\left(P_{j} C_{i}\right)+\sum \beta\left(P_{j} A_{i}\right)+\sum \beta\left(P_{j} C_{i} A_{i}\right)+\varepsilon_{i}
\end{aligned}
$$

except it also includes a metric term for age, $A_{i}$, as well as a two-way interaction between age and place of birth, $P_{j} A_{i}$ and a three-way interaction between place of birth, cohort, and age, $P_{j} C_{i} A_{i}$. The other models we estimate are simply reduced-forms of these. In the case of models for which the dependent variable is log earnings, we also add a term for age squared $\left(A_{i}^{2}\right)$ and its interactions with place of birth and cohort. That is, the last four terms of equation [2] are replicated with $A_{i}^{2}$ substituted for $A_{i}$ and added to the model. This polynomial specification permits us to assess the extent to which aging effects on earnings vary over time.

Since our analysis focuses on women, we must recognize that sample selection bias in the form of labour force nonparticipation may be present. That is, women choose whether to work or not, and that choice may not be entirely random. For example, women who would attract only low wages or qualify only for lower ranking occupations might be less likely to work, thereby biasing the observed wages and occupational distribution upward. The classic solution to this problem was proposed by Heckman (Heckman 1979) and involves estimating the hazard rate for labour force participation by means of a probit model, then including the hazard as a predictor in the earnings equation. Since we are estimating both an OLS earnings model and a logistic occupational attainment model, we have chosen instead to estimate the hazard by means of predicted probabilities of labour force participation from a logistic regression model in which participation is predicted from the place of birth dummies (to adjust for differences in propensity to work across ethnic groups), education, official language ability, marital status, number of children, and urban residence. The hazard rate from such a model simply equals the predicted probability of participation (Berk 1983).

As a result of our merger of five large data sets, our effective sample size after eliminating cases with missing values on the variables is in excess of 70,000 cases for the sequence of cohorts file and some 190,000 cases for the aging 
cohorts file. Therefore, the use of conventional p-values to test our null hypotheses is likely to result in finding even negligible trends to be statistically significant. As a result, we supplement these tests with Baysian Information Criterion (BIC) values developed by Raftery (Raftery 1995). The BIC statistic addresses the question: given the observed data, which model is more likely given the data? In the case of an OLS regression model where some hypothesized model, $\mathrm{M}_{\mathrm{k}}$, is being compared to the null model, Raftery proposes that a version of BIC based on comparisons to the null model, BIC', be defined as follows:

$$
\mathrm{BIC}_{\mathrm{k}}^{\prime}=n \log \left(1-\mathrm{R}_{\mathrm{k}}^{2}\right)+\mathrm{p}_{\mathrm{k}} \log n
$$

where $R_{k}^{2}$ represents the fit of the hypothesized model, $p_{k}$ is the number of independent variables and $n$ is the sample size. For logistic regression the measure of model fit is the $-2 \log$ likelihood contrasting the hypothesized model to the null model and BIC' is defined as:

$$
\mathrm{BIC}_{\mathrm{k}}^{\prime}=-\chi_{\mathrm{k} 0}^{2}+\mathrm{p}_{\mathrm{k}} \log n
$$

in which $-\chi_{\mathrm{k} 0}^{2}$ is the $-2 \log$ likelihood for testing the hypothesized model against the null model and $p_{k}$ is the number of degrees of freedom associated with that test.

\section{Findings}

Comparing Cohorts as They Enter the Labour Market. Figure 2 plots mean earnings expressed in constant 1996 Canadian dollars and percent in professional and managerial occupations for 25-29 year old women who arrived prior to each of the census years by place of birth. These are unadjusted using the independent variables in our models to give some sense for the patterns we wish to explain. Aside from a slight increase overall between 1971 and 1981, there appears to be no real trend in adjusted earnings. Consistently at the top of the earnings distributions are women born in Anglophone or Francophone countries, followed closely by the Canadian born. Consistently at the bottom are Black women born in Africa or the Caribbean. There is a substantial spread in mean earnings in 1971 that only increases by 1996, largely through an apparent decline in the earnings of Blacks and Southern Europeans. The story for professional and managerial occupations is somewhat different. With the exception of the extremely low representation of Southern European women in these occupations, there is relatively little spread among immigrants arriving 
prior to 1971, though those from Anglophone and Francophone countries and the Canadian born are at the top, a veritable constant across these cohorts. However, the variability increases considerably in subsequent entry cohorts, with some dramatic reshuffling of ethnic groups. In particular, Southern European women increase their share of the professional and managerial ranks after 1986, while Asian women, with the highest percentage in 1971, drop to near the bottom. Of course, the specific countries providing these Asian immigrants change over the course of the 25 -year period. In particular, by the early 1980s a substantial number of Vietnamese refugees are arriving in Canada, likely depressing the Asian representation in higher-ranking occupations.

Of course, these patterns are merely suggestive, since they do not control for the other socioeconomic characteristics that also affect earnings and occupational attainment and they do not separate immigrants who received all their education abroad from those receiving their highest credential in Canada. A summary of models that do just that, separated by location of education, is reported in Table 1. To a baseline model containing just the socioeconomic characteristics and a linear term for cohort membership we first add the dummy variables representing place of birth, then interactions between the place of birth dummies and cohort year capturing linear trends in the effects of place of birth on both log earnings and employment in professional and managerial occupations.

Among those immigrant women educated in Canada, the preferred model for both earnings and occupation contains only the socioeconomic characteristics, cohort year, and the place of birth dummies, based on the BIC criterion. That is, there are at least some significant net differences in log earnings and the likelihood of entering a higher-ranking occupation between the immigrant groups and the Canadian born, the reference category. In the case of those educated abroad, there is some evidence of linear trends across immigrant groups in earnings, but again no apparent trends in occupational attainment according to the BIC criterion.

Table 2 reports the parameters of the preferred semi-log earnings models, plus a model for immigrants educated abroad that excludes the trends parameters. Comparing the models without linear trends, it is clear that it is mainly visible minority women from Asia, Africa, the Caribbean, and Latin America who earn less than Canadian-born women. However, these effects are considerably larger for immigrants who were educated abroad, with Blacks earning some 28 percent less than Canadian-born women. Surprisingly, net of the controls women from Anglophone and Francophone countries who were educated there also earn somewhat less than the Canadian-born. The third column reports the preferred model for immigrants educated abroad. As is evident from the coefficients associated with the birthplace dummies, European-born immigrants except for 
Figure 2

Mean Earnings and Percent in Professional and Managerial Occupations, Female Immigrants to Canada Age 25-29 in 1971, 35-39 in 1981, 40-44 in 1986, 45-49 in 1991, and 50-54 in 1996 by Region of Birth
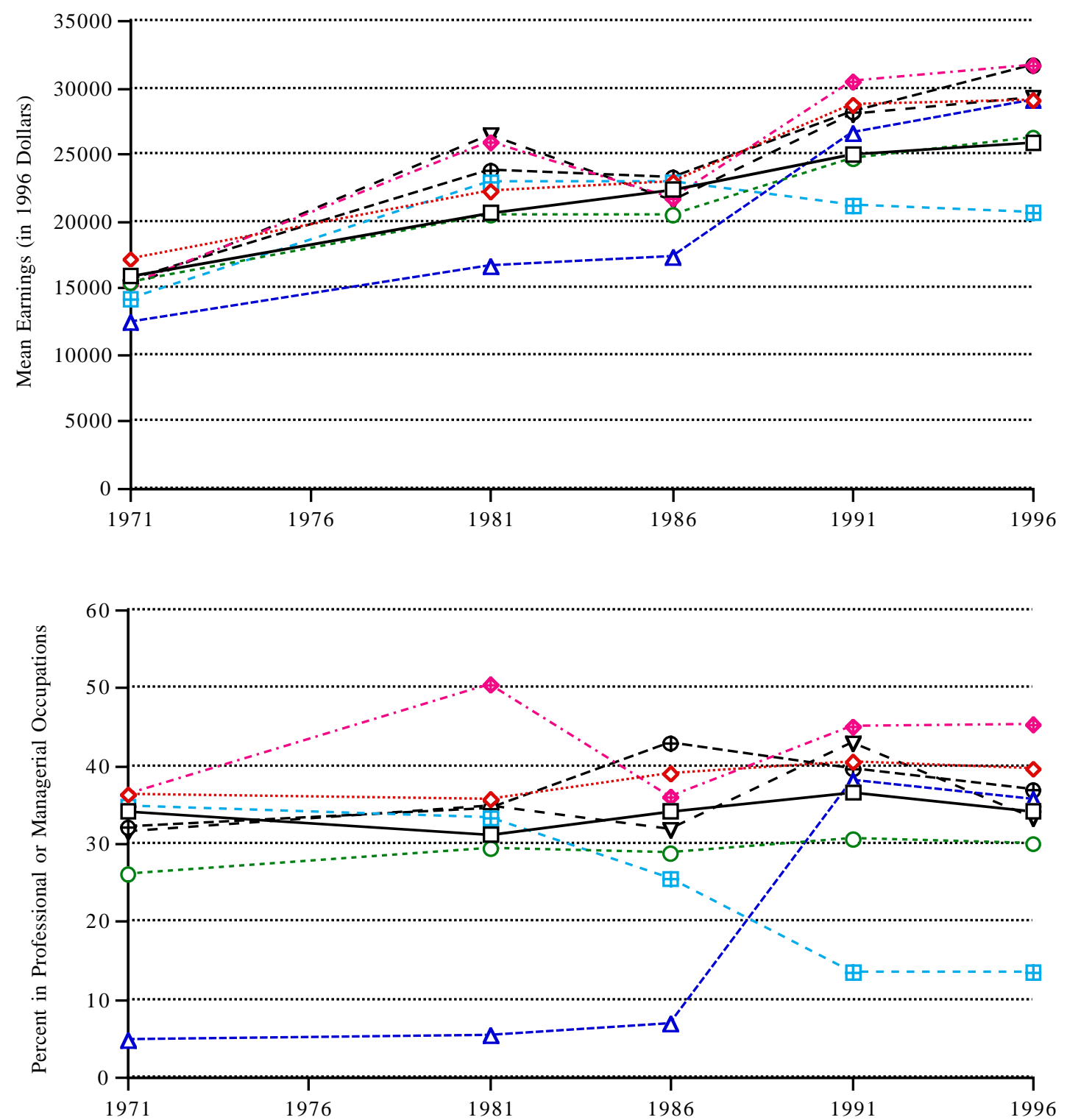

\begin{tabular}{|c|c|c|c|}
\hline$\square$ & Canada & $\cdots \cdots \cdots \cdots$ & Anglophone or Francophone Countries \\
\hline$-\cdots--$ & Northwestern Europe & $----\Delta---$ & Southern Europe \\
\hline - - -田- - & Eastern Europe & $-\cdot-\cdot-\cdot$ & Asia \\
\hline$---\oplus--$ & Caribbean or African Blacks & $--\nabla--$ & Latin America \\
\hline
\end{tabular}




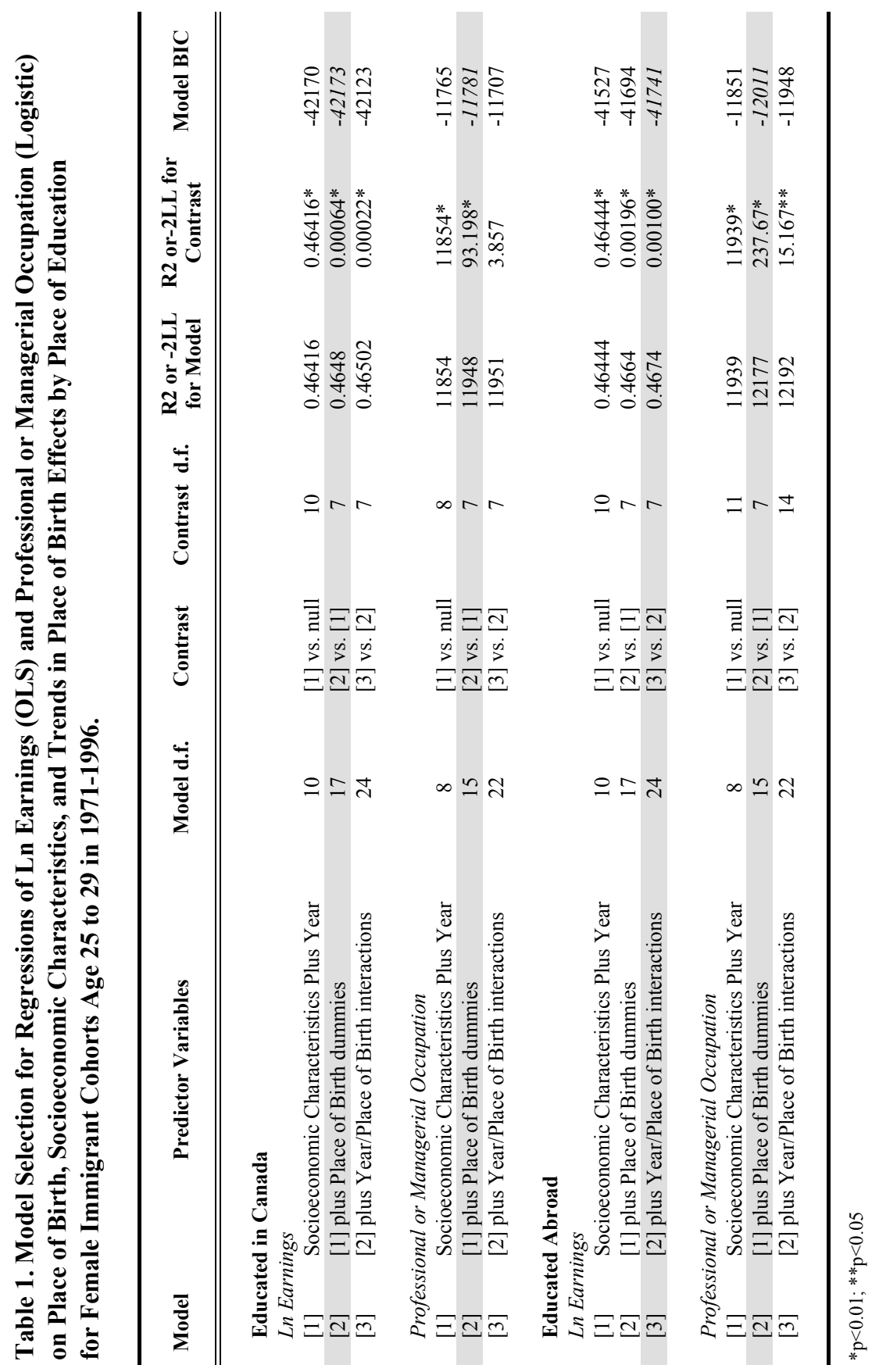


Table 2

Unstandardized Coefficients for the OLS Regression of Log Earnings on Entry Cohort Year, Birth Place, and Socioeconomic Characteristics, Female Immigrants Age 25-29 Arriving Prior to Census Years 1971-1996

\begin{tabular}{|c|c|c|c|}
\hline \multirow[b]{2}{*}{ Independent Variables } & \multirow{2}{*}{$\begin{array}{c}\text { Educated in Canada } \\
\text { Model [2] }\end{array}$} & \multicolumn{2}{|c|}{ Educated Abroad } \\
\hline & & Model [2] & Model [3] \\
\hline \multicolumn{4}{|l|}{ Socioeconomic Characteristics } \\
\hline Entry Cohort Year & $-2.553 *$ & $-2.609 *$ & $-2.500^{*}$ \\
\hline Graded Schooling & $6.481 *$ & $5.921 *$ & $6.277^{*}$ \\
\hline Postsecondary Schooling & $6.654 *$ & $6.839 *$ & $6.784 *$ \\
\hline Speaks Official Language & -1.097 & $9.921 *$ & 6.339 \\
\hline Married & $10.71 *$ & $10.76^{*}$ & $10.81 *$ \\
\hline Number of children & $-10.08 *$ & $-11.85^{*}$ & $-11.88^{*}$ \\
\hline Urban Residence & $15.34 *$ & $15.75^{*}$ & $15.60 *$ \\
\hline Weeks Worked & $3.433 *$ & $3.434 *$ & $3.444 *$ \\
\hline Part-time Work & $-65.41 *$ & $-64.78^{*}$ & $-64.68 *$ \\
\hline $\operatorname{Pr}$ (Labour Force Participation) & $-40.25 *$ & $-69.90 *$ & $-71.73 *$ \\
\hline \multicolumn{4}{|l|}{ Birth Place } \\
\hline Anglo- or Francophone Countries & 0.442 & $-8.174 *$ & $18.65^{*}$ \\
\hline Northwestern Europe & -5.151 & -1.082 & $34.01 *$ \\
\hline Southern Europe & $-11.12 *$ & 0.093 & $48.98 *$ \\
\hline Eastern Europe & 0.87 & 2.203 & 10.7 \\
\hline Asia & $-11.10^{*}$ & $-24.05^{*}$ & $-22.47^{*}$ \\
\hline Caribbean or African Black & $-17.00 *$ & $-27.78^{*}$ & $-28.78^{*}$ \\
\hline Latin America & $-13.44 *$ & $-21.79 *$ & -9.839 \\
\hline \multicolumn{4}{|l|}{ Interactions (Linear Trends) } \\
\hline Anglo or Francophone by Year & & & $-2.022^{*}$ \\
\hline NW Europe by Year & & & $-2.709^{*}$ \\
\hline S Europe by Year & & & $-3.861 *$ \\
\hline E Europe by Year & & & -0.444 \\
\hline Asia by Year & & & -0.061 \\
\hline Caribbean/Africa by Year & & & 0.064 \\
\hline Latin America by Year & & & -0.674 \\
\hline Constant & 883.8 & 917.9 & 913.1 \\
\hline $\mathrm{R}^{2}$ & 0.458 & 0.459 & 0.46 \\
\hline
\end{tabular}

Note: All coefficients have been multiplied by 100 for ease of presentation.

${ }^{*} \mathrm{p}<0.01$ 
those from Eastern Europe had considerably higher net earnings in 1971 than the Canadian born, but they declined at a sizeable rate for successive cohorts of immigrants. The much lower earnings of visible minority women in 1971 remained low throughout the period, as the nonsignificant trend coefficients attest.

As indicated above, we found no evidence for linear trends in the odds of women immigrants aged 25-29 entering a professional or managerial occupation compared to the Canadian born, since the preferred models for both those educated in Canada and those educated abroad include only effects of the controls and birth place. Table 3 reports the parameters of the preferred models. All the odds ratios associate with place of birth

shown there are less than one, indicating lower odds of entering professional or managerial occupations for immigrants than for the native born. However, among those educate in Canada the only significant effects are for those women from Northwestern Europe, Southern Europe, and Asia, hence it is not apparent that it is only members of visible minority groups that experience discrimination in this regard. Among those educated abroad, every immigrant group has a reduced likelihood of entering higher status occupations net of the controls, though the odds are the lowest for women born in Asia or Latin America. As well, the odds ratios among those with foreign credentials are generally lower than for those educated in Canada, particularly in the case of visible minority women. This again confirms the value of Canadian education in the Canadian labour market and the difficulties immigrants face in having their foreign credentials recognized.

Comparing Cohorts Across the Career. Our next task is to examine trends in earnings and occupational attainments across the careers of women immigrants in arrival cohorts stretching from before 1971 to before 1991. This will be accomplished by modeling the earnings and occupational attainment of cases along the shaded diagonals in Figure 1. Table 4 summarizes these models separately for those educated in Canada and abroad. In this case, the contrast between these two groups of immigrants is striking. For the former, the preferred earnings model based on the BIC criterion is actually the baseline model containing only controls plus entry cohort and age. In other words, there does not even appear to be any important differences in earnings between immigrants with Canadian credentials and the Canadian born. In the case of the occupational attainment of Canadian educated immigrants, there are some significant place of birth effects, but no evidence of trends either across cohorts or through the career. As well, there appear to be no trends in the occupational attainment of those educated abroad compared to the Canadian born. The patterns of differences between immigrant groups are similar to those reported 
Trends in the Occupational and Earnings Attainment

of Women Immigrants to Canada, 1971-1996

Table 3

Odds Ratios for the Logistic Regression of Professional or Managerial Occupation on Entry Cohort Year, Birth Place, and Controls, Female Immigrants Age 25-29 Arriving Prior to Census Years 1971-1996

\begin{tabular}{lll}
\hline \multicolumn{1}{c}{ Independent Variable } & $\begin{array}{c}\text { Educated } \\
\text { in Canada }\end{array}$ & $\begin{array}{c}\text { Educated } \\
\text { Abroad }\end{array}$ \\
\hline \hline Socioeconomic Characteristics & & \\
Entry Cohort Year & $0.973^{*}$ & $0.973^{*}$ \\
Graded Schooling & $1.446^{*}$ & $1.446^{*}$ \\
Postsecondary Schooling & $1.611^{*}$ & $1.620^{*}$ \\
Speaks Official Language & 0.483 & $0.403^{*}$ \\
Married & $1.195^{*}$ & $1.198^{*}$ \\
Number of children & $0.849^{*}$ & $0.860^{*}$ \\
Urban Residence & 0.990 & 0.983 \\
Pr(Labour Force Participation) & 0.360 & 0.439 \\
Birth Place & & \\
Anglo- or Francophone Countries & 0.949 & \\
Northwestern Europe & $0.616^{*}$ & $0.807^{*}$ \\
Southern Europe & $0.446^{*}$ & $0.677^{*}$ \\
Eastern Europe & 0.903 & $0.658^{*}$ \\
Asia & $0.676^{*}$ & $0.555^{*}$ \\
Caribbean or African Black & 0.826 & $0.408^{*}$ \\
Latin America & 0.900 & $0.606^{*}$ \\
-2 Log Likelihood & & $0.440^{*}$ \\
N of Cases & 73152 & 70681 \\
\hline & 67047 & 65897 \\
\hline
\end{tabular}

$* \mathrm{p}<0.01 * * \mathrm{p}<0.05$ 


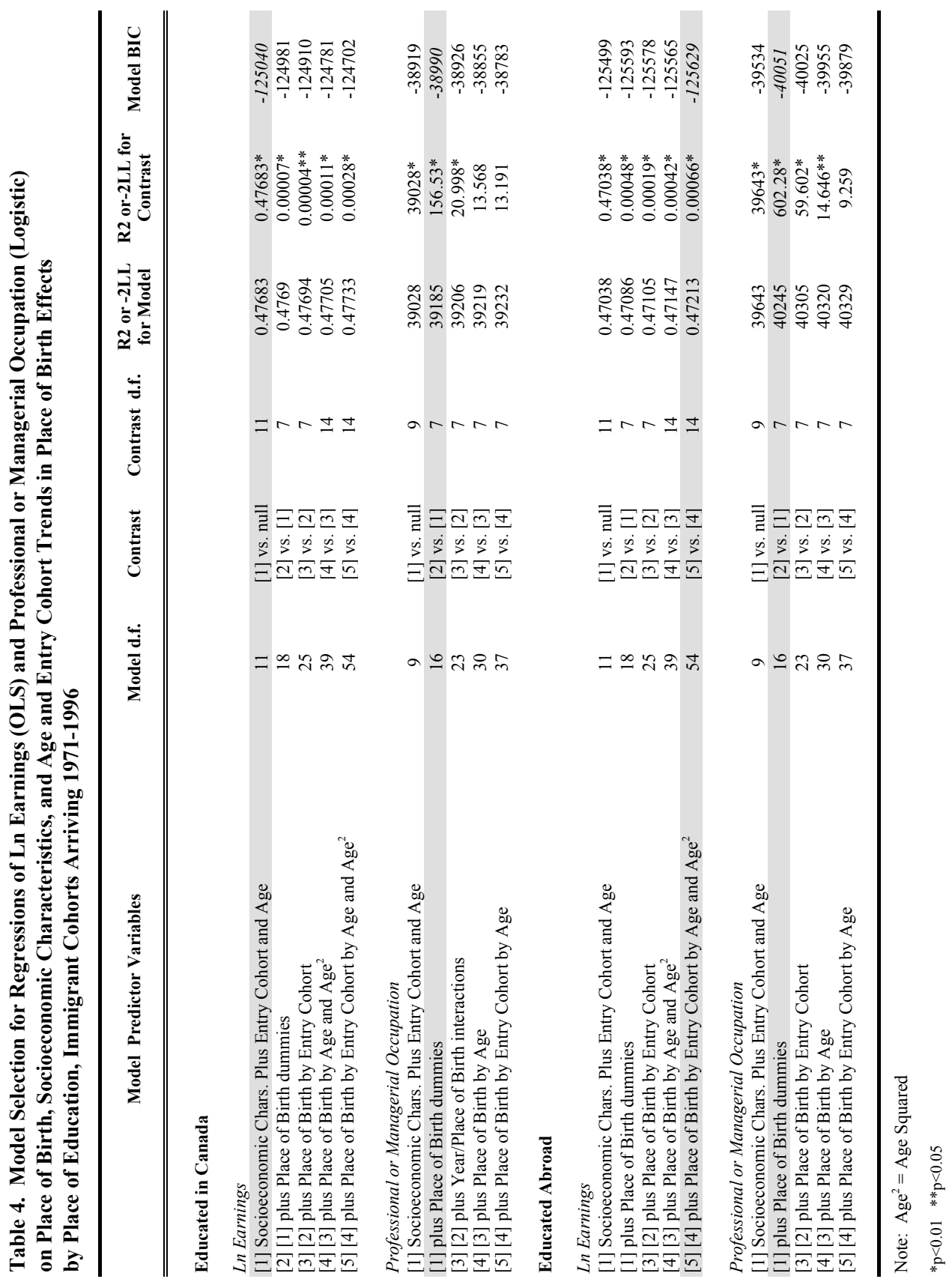


in Table 3. The odds of attaining a professional or managerial occupation are consistently lower for immigrants than the Canadian born, and the lowest odds are found among those who hold foreign credentials. The lack of trends either over time or through the career suggests that there is both no evidence that more recent cohorts of immigrants attain inferior occupations given their level of education compared to earlier cohorts and no evidence of career mobility among these women.

The results for the earnings models estimated for those whose education was completed outside Canada are strikingly different. From Table 4 the preferred model in this case is the model containing two-way interactions between the place of birth dummies and age, age-squared, and entry cohort as well as the three-way interaction among these variables. In other words, there are significant earnings trends across entry cohorts and across the career, and the career trends vary by cohort. Table 5 presents parameter estimates for models [2], [4], and [5]. The main effects of place of birth are similar to what we saw in models for cohort differences within a single age group above: by far the largest departures from the earnings of the Canadian born are found among members of visible minorities immigrating from Asia, Africa or the Caribbean, and Latin America. Model [4] incorporates two-way interactions between age and place of birth and entry cohort and place of birth reflecting linear trends over time and over the career. While there is again no evidence that the earnings liabilities of members of visible minority groups have increased from earlier to more recent entry cohorts, the earnings of those from Southern Europe relative to the Canadian born have. As for trends over the career disregarding cohort, there is evidence that the earnings of Asians actually converged somewhat with those of the Canadian born, while the earnings of most European groups actually diverged over the career. However, we must recall that visible minority members' earnings are considerably below those of both the Canadian-born majority and European immigrants in the earliest cohort and youngest age represented here, as reflected in the place of birth coefficients in Model [4].

Finally, Model [5] includes three-way interactions among age, entry cohort, and place of birth telling us the extent to which career trends in earnings differ by cohort. The positive sign and approximately equal values of these estimates suggests that as we move from the earliest to the most recent entry cohorts, the relative earnings of all place of birth groups tend to converge slightly but significantly with the earnings of the Canadian born over the course of the career. In other words, the earnings of more recent immigrant cohorts show signs of catching up with those of the Canadian born.

These interaction effects are best interpreted in Figure 3, which shows the log earnings by age, entry cohort, and place of birth predicted from Model [5] of 
Table 5

Unstandardized Coefficients for the OLS Regression of Log Earnings on Entry Cohort Year, Age, Birth Place, Socioeconomic Characteristics, and Trends in Place of Birth Effects by Age and Entry Cohort, Female Immigrants Age 25-54 Arriving Prior to Census Years 1971-1996 and Educated Abroad

\begin{tabular}{|c|c|c|c|}
\hline Independent Variables & Model [2] & Model [4] & Model [5] \\
\hline \multicolumn{4}{|l|}{ Socioeconomic Characteristics } \\
\hline Entry Cohort Year & $-1.630^{*}$ & $-1.569 *$ & $-1.572 *$ \\
\hline Age & $3.950 *$ & $4.080 *$ & $4.059 *$ \\
\hline Age Squared & $-0.056^{*}$ & $-0.057 *$ & $-0.057^{*}$ \\
\hline Graded Schooling & $8.475 *$ & $8.632 *$ & $8.680^{*}$ \\
\hline Postsecondary Schooling & $9.758 *$ & $9.745^{*}$ & $9.774 *$ \\
\hline Speaks Official Language & 4.933 & 2.785 & 3.286 \\
\hline Married & $6.445 *$ & $6.334 *$ & $6.112 *$ \\
\hline Number of children & $-6.321 *$ & $-6.386^{*}$ & $-6.458 *$ \\
\hline Urban Residence & $15.08 *$ & $15.03 *$ & $15.09 *$ \\
\hline Weeks Worked & $3.629 *$ & $3.633 *$ & $3.642 *$ \\
\hline Part-time Work & $-66.5^{*}$ & $-66.42 *$ & $-66.35^{*}$ \\
\hline Pr(Labour Force Participation) & $-117.9^{*}$ & $-122.1^{*}$ & $-130.3^{*}$ \\
\hline \multicolumn{4}{|l|}{ Birth Place } \\
\hline Anglo- or Francophone Countries & $-6.314 *$ & $98.85^{*}$ & $407.8 *$ \\
\hline Northwestern Europe & -3.426 & $282.5 *$ & $635.1 *$ \\
\hline Southern Europe & -3.353 & $334.5 *$ & $710.2 *$ \\
\hline Eastern Europe & $5.367 *$ & 0.433 & $295.0 *$ \\
\hline Asia & $-12.89^{*}$ & $-76.58 *$ & 19.7 \\
\hline Caribbean or African Black & $-9.462 *$ & $-123.4 * *$ & -3.701 \\
\hline Latin America & $-7.477^{*}$ & -25.47 & $197.1^{*}$ \\
\hline \multicolumn{4}{|l|}{ Linear Trends with Entry Cohort } \\
\hline Anglo or Francophone by Entry Cohort & & -0.4 & $-35.80 *$ \\
\hline NW Europe by Entry Cohort & & -0.725 & $-62.45^{*}$ \\
\hline S Europe by Entry Cohort & & $-3.605 *$ & $-41.6^{*}$ \\
\hline E Europe by Entry Cohort & & 0.015 & $-25.73 *$ \\
\hline Asia by Entry Cohort & & -0.253 & -2.965 \\
\hline Caribbean/Africa by Entry Cohort & & 0.332 & -3.169 \\
\hline Latin America by Entry Cohort & & -0.628 & $-15.86^{* *}$ \\
\hline
\end{tabular}


Table 5 (Continued)

Unstandardized Coefficients for the OLS Regression of Log Earnings on Entry Cohort Year, Age, Birth Place, Socioeconomic Characteristics, and Trends in Place of Birth Effects by Age and Entry Cohort, Female Immigrants Age 25-54 Arriving Prior to Census Years 1971-1996 and Educated Abroad

\begin{tabular}{|c|c|c|c|}
\hline Independent Variables & Model [2] & Model [4] & Model [5] \\
\hline \multicolumn{4}{|l|}{ Linear Trends with Age and Age ${ }^{2}$} \\
\hline Anglo or Francophone by Age & & $-5.114 *$ & $-20.29 *$ \\
\hline NW Europe by Age & & $-14.36^{*}$ & $-31.60^{*}$ \\
\hline S Europe by Age & & $-14.25 *$ & $-33.41 *$ \\
\hline E Europe by Age & & 0.135 & $-13.75^{*}$ \\
\hline Asia by Age & & $3.196 * *$ & -1.572 \\
\hline Caribbean/Africa by Age & & 4.813 & -0.975 \\
\hline Latin America by Age & & 1.045 & -10.19 \\
\hline Anglo or Francophone by $\mathrm{Age}^{2}$ & & $0.061 *$ & $0.240 *$ \\
\hline NW Europe by Age $^{2}$ & & $0.175^{*}$ & $0.377^{*}$ \\
\hline S Europe by $\mathrm{Age}^{2}$ & & $0.147 *$ & $0.381^{*}$ \\
\hline 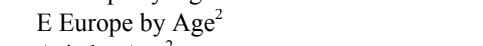 & & 0 & $0.159^{*}$ \\
\hline Asia by $\mathrm{Age}^{2}$ & & -0.035 & 0.021 \\
\hline Caribbean/Africa by $\mathrm{Age}^{2}$ & & -0.047 & 0.021 \\
\hline Latin America by $\mathrm{Age}^{2}$ & & -0.009 & $0.126^{* *}$ \\
\hline \multicolumn{4}{|l|}{ Differences in Age and Age ${ }^{2}$ Trends by Cohort } \\
\hline Anglo or Francophone by Age by Cohort & & & $1.777^{*}$ \\
\hline NW Europe by Age by Cohort & & & $3.245^{*}$ \\
\hline S Europe by Age by Cohort & & & $1.765^{*}$ \\
\hline E Europe by Age by Cohort & & & $1.258^{*}$ \\
\hline Asia by Age by Cohort & & & 0.082 \\
\hline Caribbean/Africa by Age by Cohort & & & 0.101 \\
\hline Latin America by Age by Cohort & & & 0.742 \\
\hline Anglo or Francophone by $\mathrm{Age}^{2}$ by Cohort & & & $-0.021^{*}$ \\
\hline NW Europe by $\mathrm{Age}^{2}$ by Cohort & & & $-0.041^{*}$ \\
\hline S Europe by $\mathrm{Age}^{2}$ by Cohort & & & -0.018 \\
\hline E Europe by $\mathrm{Age}^{2}$ by Cohort & & & $-0.015 * *$ \\
\hline Asia by $\mathrm{Age}^{2}$ by Cohort & & & 0 \\
\hline Caribbean/Africa by $\mathrm{Age}^{2}$ by Cohort & & & 0 \\
\hline Latin America by $\mathrm{Age}^{2}$ by Cohort & & & -0.008 \\
\hline Constant & 843.4 & 842 & 849.235 \\
\hline $\mathrm{R}^{2}$ & 0.471 & 0.471 & 0.472 \\
\hline
\end{tabular}

Note: Age $^{2}=$ Age Squared

All coefficients have been multiplied by 100 for ease of presentation.

${ }^{*} \mathrm{p}<0.01 * * \mathrm{p}<0.05$ 
Figure 3

Predicted Relative Earnings by Age, Entry Cohort, and Place of Birth for Female Immigrants Educated Abroad
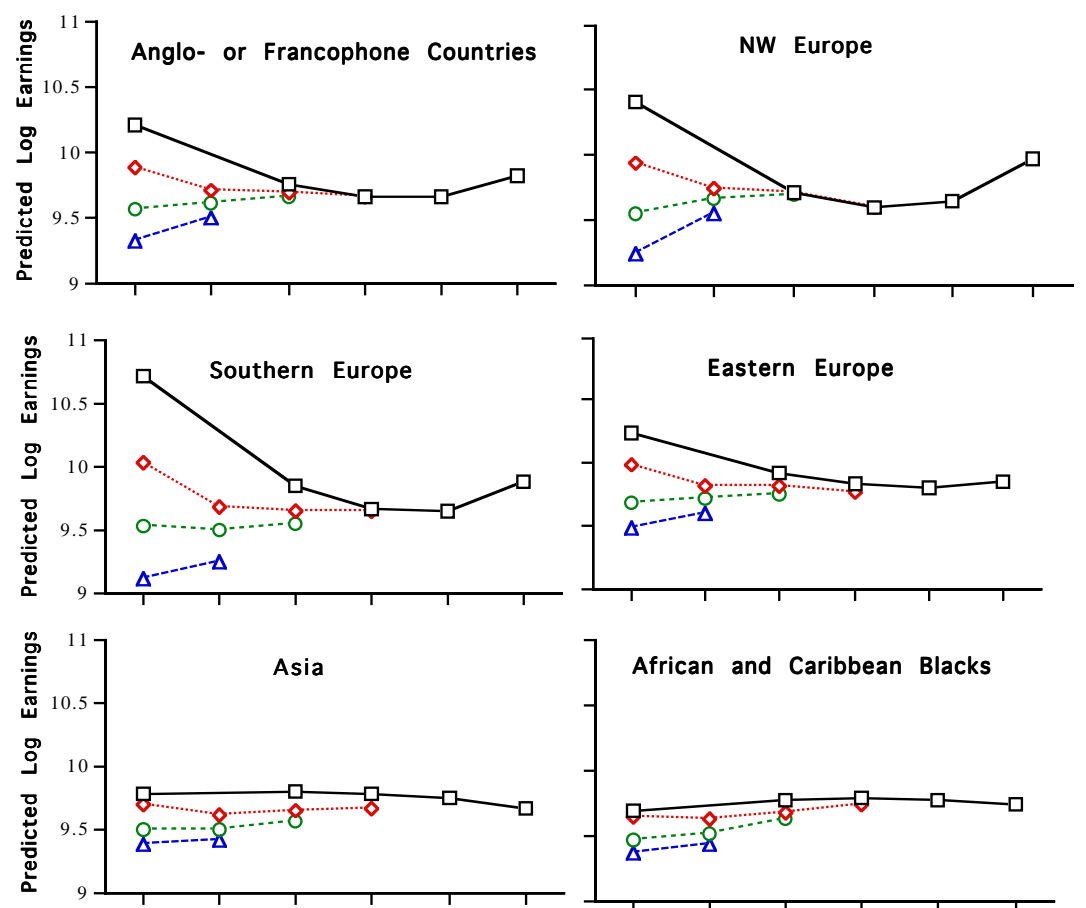

African and Caribbean Blacks
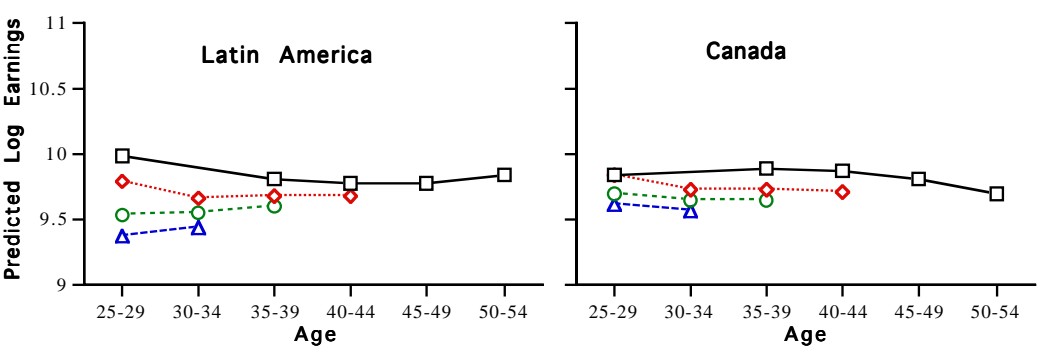

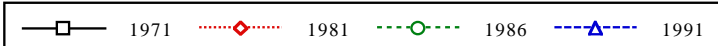


Table 5. ${ }^{4}$ The baseline for comparison is the Canadian-born in the lower righthand corner. For the native-born respondents with the longest series of data points, the cohort first observed prior to the 1971 census, earnings increase slightly to age 35-39, and then decline. Subsequent cohorts then show increasingly lower earnings at all age levels. ${ }^{5} \quad$ However, these declines from cohort to cohort for Canadian-born women are considerably less than those observed in the graphs for immigrant women. Surprisingly, the largest declines are observed for women of various European origins. While in the cohort entering Canada prior to 1971 these women had earnings considerably higher than those of the Canadian born early in their careers (age 25-29), more recent cohorts are characterized by increasingly lower early-career earnings. This is depicted graphically in Figure 3, while parameters representing these effects can be seen in Model [3] in Table 2.

The real utility of Figure 3, however, is that it permits us to see how earnings unfold over the career and compare the earnings of immigrant women from various origins and different arrival cohorts. As confirmed by the tests reported in Model [5] in Table 5, the earnings of all European-origin groups decline in the cohorts entering before 1971 and before 1981. In more recent cohorts, these women's earnings are either flat or actually increase somewhat as their careers unfold. In the case of women from Asia, Africa, the Caribbean, and Latin America, there is no evidence of either declining earnings from cohort to cohort (the small differences observed in the graphs are nonsignificant) or a trend toward increasing earnings across the career. Indeed, the earnings trajectories for these groups are quite similar to those of the Canadian-born, except their earnings in more recent arrival cohorts are significantly lower, though they show signs of convergence in more recent arrival cohorts.

\section{Discussion}

As we anticipated based on the implications of queuing theory and previous research (Li 2001; Wanner 1998), possessing Canadian education is a potent antidote to the tendency for women immigrants to earn lower wages and enter lower status occupations than their Canadian-born counterparts. While at the early stage of their careers, immigrant women educated in Canada still tend to have lower earnings than the Canadian born, particularly Asian, Black Caribbean and African, and Latin American women, as they proceed through their careers we could find no evidence of earnings differences between immigrants and the Canadian born. The situation of those with foreign credentials is considerably different. Both their earnings and their likelihood of practicing a higher status occupation are considerably lower than those of the Canadian born, particularly for non-European women. For those visible minority 
immigrants just beginning their careers, we could find no evidence that more recent cohorts have lower attainments than earlier cohorts, though this was true for the European groups. In our analysis of aging cohorts arriving before 1971 to 1991, we could find no evidence of career mobility. That is, the proportions of each immigrant group in professional and managerial occupations remained the same over their careers. We did, however, find some evidence of a tendency for immigrant earnings to converge with those of the Canadian born and for that tendency to be stronger in more recent cohorts.

Although we do not explicitly consider it here, the situation of immigrant men over the same time period is analyzed in a companion paper (Wanner 2003b). In contrast to the slight rise in inflation-adjusted earnings since 1971 among women in successive immigrant cohorts regardless of country of origin, men's relative earnings actually declined between 1981 and 1996. As well, immigrant men who were members of visible minorities had considerably lower earnings and were less likely to attain managerial or professional occupations net of the controls than was the case for immigrant women. Nevertheless, we found the same pattern of convergence toward the earnings of the Canadian born over the career among men that we observed here for women.

While we expected to find that visible minority women's attainments are initially lower and remain lower than those of Canadian-born women, we were surprised to note that the earnings and occupational attainments of women originating in Southern Europe (primarily Italy, Greece, and Portugal) are every bit as low as those of minority women, even when they possess Canadian credentials, as are the attainments of women from Eastern Europe who were educated abroad. This certainly calls into question simplistic versions of prejudice/discrimination theory that rely on social distance from the majority in explaining the lower attainments of minority group members. A variant on Borjas's selection hypothesis that takes into account immigrants originating from less developed regions or sectors of the population with fewer skills appropriate to an urban labour market may account for it, but a fuller understanding would require us to go beyond what is available in census data.

We were frankly surprised to see how much higher the earnings of foreigneducated women from the regions of Europe arriving prior to 1971 were than the earnings of Canadian-born women during that period. However, this finding is consistent with that of Beach and Worswick (1993) using the 1973 Canadian Mobility Study data (Boyd, Goyder, Jones, McRoberts, Pineo, and Porter 1985). Although they did not distinguish female immigrants by country of origin due to a relatively small sample size, they found that the earnings of foreign born workers were approximately 12 to 14 percent higher on average than those of Canadian-born women, and they found no evidence of convergence of earnings 
as the immigrants' number of years in Canada increased. ${ }^{6}$ Of course, the immigrant women they studied arrived in Canada before 1973 primarily from European countries and the United States. Their interpretation of this finding is that these immigrant women simply worked longer hours and more intensively than Canadian-born women to both help their families become established in Canada and to assist their husbands in obtaining language skills and Canadian credentials before they themselves entered the Canadian labour market. In support of this explanation, Beach and Worswick find that their immigrant women indeed worked significantly more hours than native-born women, but the difference decreases with time in Canada. Based on the results reported here, this explanation would appear to apply only to women arriving prior to 1971 from European countries of origin, since the pattern is not observed in later cohorts or among women arriving from other parts of the world. This certainly calls into question the generality of the explanation.

These results have two main policy implications. Given the dramatic increase in the proportion of immigrants who arrive in Canada from less developed countries under family reunification and refugee programs since the late 1970s, and hence not screened for skills under the point system, it is encouraging that we find little evidence that the earnings and occupational attainments of women from Asia, Africa, the Caribbean and Latin America are any lower than those of earlier cohorts. Although they are lower than those of the Canadian-born early in the career, there is some evidence of convergence of earnings in more recent cohorts. Indeed, other recent research finds that the earnings of refugees and family class immigrants converge with those of immigrants screened by the point system well within the span of a career (Li 2003; Wanner 2003a).

A second policy implication rests on the finding that it is mainly those educated abroad whose opportunities in the labour market are below those of the Canadian born. On the one hand, neoclassical economists would be inclined to see this result as a consequence of the lower quality of both foreign education and experience, particularly in Third World countries, and hence the lower productivity of such workers. On the other hand, sociological research into the question has tended to view the devaluing of foreign credentials in the Canadian labour market as yet another form of exclusionary discrimination (McDade 1988), particularly since it seems to be particularly directed at members of visible minority groups who immigrate from less developed countries. Every Canadian seems to have a story about the Pakistani-trained medical doctor who is cleaning offices. Of the theories discussed above, queuing theory offers the most compelling explanation: whether true or not, foreign credentials are viewed by many host country employers as signals of lower productivity, and persons offering them on the labour market are moved back in the queue for better jobs. A more structural explanation is offered by dual labour market theory (see 
Richard A. Wanner and Michelle Ambrose

Massey and Ali Kouaouci 1993). As native born women and younger workers entering the labour market become less likely to accept employment in the less desireable jobs available in the secondary labour market, it is in the interest of employers in that sector to encourage government to increase the number of immigrants, but to ignore the credentials they bring with them to fill these less desireable jobs at low wages. Regardless of the explanation, governments at all levels must be actively involved in assisting immigrants to interpret their foreign credentials for employers, educating employers about their potential value in the Canadian labour market, and facilitating the acquisition of Canadian credentials among immigrants lacking them.

\section{Acknowledgements:}

The research reported here was supported by a grant from the Social Sciences and Humanities Research Council of Canada and Citizenship and Immigration Canada through the Prairie Centre of Excellence for Research on Immigration and Integration.

\section{End Notes:}

1. Much of what we know of the occupational and earnings attainments of women immigrants in particular is based on now dated research using single cross-sectional data sets. Examples include Basavarajappa and Verma (1990) and Boyd (1990), who relied on data from the 1981 Census of Canada, and Boyd (1984; 1985) and Beach and Worswick (1993), who used data from the 1973 Canadian Mobility Study.

2. Canada actually carries out a census every five years. However, the 1976 census was little more than a population count and measured so few variables that it is not useable for the sort of research reported here.

3. Categories of the SOC coded 1 are: managerial, administrative and related (occupations); natural sciences, engineering and mathematics; social sciences and related; teaching and related; occupations in medicine and health; and artistic, literary, recreational, and related.

4. These predicted values were computed by substituting the means of all variables but age, entry cohort, and place of birth into the equation represented by Model [5] of Table 5. By then varying the 
Trends in the Occupational and Earnings Attainment

of Women Immigrants to Canada, 1971-1996

values of age, entry cohort, and place of birth we were able to produce the values plotted in the respective graphs.

5. The decline in both absolute and relative earnings among younger workers in Canada has been documented elsewhere (Kapsalis et al. 1999) and is consistent with the general trend toward greater income inequality observed in most postindustrial countries since the early 1970s.

6. Beach and Worswick (1993) qualify this finding by showing that an earnings advantage was limited to women with lower levels of formal education. Their results show that better educated immigrant women had considerably lower earnings than nativeborn women with a similar level of education.

\section{References:}

Beach, Charles M. and Christopher Worswick. 1993. "Is There a DoubleNegative Effect on the Earnings of Immigrant Women?" Canadian Public Policy 19: 36-53.

Becker, Gary. 1971. The Economics of Discrimination. Chicago: University of Chicago Press.

Berk, Richard A. 1983. "An Introduction to Sample Selection Bias in Sociological Data,” American Sociological Review 48: 386-398.

Bloom, David E., Gilles Grenier, and Morley Gunderson. 1995. "The Changing Labour Market Position of Canadian Immigrants," Canadian Journal of Economics 28: 987.

Borjas, George J. 1987. "Self-Selection and the Earnings of Immigrants," American Economic Review 77: 531-553.

Borjas, George J. 1993. "Immigration Policy, National Origin, and Immigrant Skills: A Comparison of Canada and the United States," in Small Differences that Matter: Labor Markets and Income Maintenance in Canada and the United States, edited by D. Card and R. B. Freeman. Chicago: University of Chicago Press. Pp. 21-43.

Borjas, Geroge J. 1994. "The Economics of Immigration,” Journal of Economic Literature 32: 1167-1717. 
Richard A. Wanner and Michelle Ambrose

Boyd, Monica. 1984. "At a Disadvantage: The Occupational Attainments of Foreign-Born Women in Canada," International Migration Review 18: 1091-1119.

Boyd, Monica. 1992a. "Gender Issues in Immigration and Language Fluency.," in Immigration, Language, and Ethnicity: Canada and the United States, edited by B. R. Chiswick. Washington, D. C.: American Enterprise Institute. Pp. 305-372.

Boyd, Monica. 1992b. "Gender, Visible Minority, and Immigrant Earnings Inequality: Reassessing an Employment Equity Promise," in Deconstructing a Nation: Immigration, Multiculturalism, and Racism in '90s Canada, edited by V. Satzewich. Halifax: Fernwood Publishing. Pp. 279-321.

Boyd, Monica, John Goyder, Frank E. Jones, Hugh A. McRoberts, Peter C. Pineo, and John Porter. 1985. Ascription and Achievement: Studies in Mobility and Status Attainment in Canada. Ottawa: Carleton University Press.

Cunningham, Annacost Nicola. 1995. "Gender and Immigration Law: The Recruitment of Domestic Workers to Canada, 1867-1940," Indian Journal of Gender Studies 2: 25-43.

DeSilva, Arnold. 1992. Earnings of Immigrants: A Comparative Analysis. Ottawa: Economic Council of Canada.

Evans, M. D. R. and Jonathan Kelley. 1991. "Prejudice, Discrimination, and the Labor Market: Attainments of Immigrants in Australia," American Journal of Sociology 97: 721-759.

Green, Alan G. and David A. Green. 1999. "The Economic Goals of Canada's Immigration Policy: Past and Present," Canadian Public Policy 25: 425-451.

Green, David A. 1999. "Immigrant Occupational Attainment: Assimilation and Mobility over Time," Journal of Labor Economics 17: 49-79.

Heckman, James J. 1979. "Sample Selection Bias as a Specification Error," Econometrica 47: 153-61. 
Trends in the Occupational and Earnings Attainment

of Women Immigrants to Canada, 1971-1996

Hodge, R. W. 1973. "Toward a Theory of Racial Differences in Employment," Social Forces 52: 16-31.

Kapsalis, C., R. Morissette, and G. Picot. 1999. "The Returns to Education and the Increasing Wage Gap Between Older and Younger Workers," Statistics Canada, Ottawa.

Kelley, Ninette and Michael Trebilcock. 1998. The Making of the Mosaic: A History of Canadian Immigration Policy. Toronto: University of Toronto Press.

Li, Peter S. 2001. "The Market Worth of Immigrants' Educational Credentials," Canadian Public Policy 27: 23-38.

Li, Peter S. 2003. Destination Canada: Immigration Debates and Issues. Toronto: Oxford University Press.

Lieberson, S. 1980. A Piece of the Pie: Blacks and White Immigrants since 1880. Berkeley: University of California Press.

Massey, Douglas S., Joaquin Arango, Graeme Hugo, and Adela Pellegrina Ali Kouaouci, and J. Edward Taylor. 1993. "Theories of International Migration: A Review and Appraisal," Population and Development Review 19: 431-466.

McDade, Kathryn. 1988. Barriers to Recognition of the Credentials of Immigrants in Canada. Ottawa: Institute for Research on Public Policy.

Morissette, R., J. Myles, and G. Picot. 1994. "Earnings Inequality and the Distribution of Working Time in Canada," Canadian Business Economics 2: 3-16.

Pendakur, Krishna and Ravi Pendakur. 1998. "The Colour of Money: Earnings Differentials Among Ethnic Groups in Canada," Canadian Journal of Economics 31: 518-548.

Pendakur, Ravi. 2000. Immigrants and the Labour Force: Policy, Regulation, and Impact. Montreal \& Kingston: McGill-Queen's University Press.

Prefontaine, J.P. and Andrew Benson. 1999. "Barriers to Canadian Immigrants' Economic Integration: Government Response to Market Failure," Third National Metropolis Conference. Vancouver, B.C. 
Richard A. Wanner and Michelle Ambrose

Raftery, Adrian E. 1995. "Baysian Model Selection in Social Research," Sociological Methodology 25: 111-163.

Ruddick, Elizabeth. 1999. "The Recent Economic Performance of Immigrants." Third National Metropolis Conference. Vancouver, B.C.

Sorenson, Marianne. 1995. "The Match Between Education annd Occupation for Immigrant Women in Canada," Canadian Ethnic Studies 27: 49-66.

Thurow, L. C. 1975. Generating Inequality. New York: Basic Books.

Wanner, Richard A. 1998. "Prejudice, Profit, or Productivity: Explaining Returns to Human Capital among Male Immigrants to Canada," Canadian Ethnic Studies 30: 24-55.

Wanner, Richard A. 2003a. "Entry Class and the Earnings Attainment of Immigrants to Canada, 1980-1996," Canadian Public Policy 29: 53-71.

Wanner, Richard A. 2003b. "Shifting Origins, Shifting Labour Markets: Trends in the Occupational and Earnings Attainments of Male Immigrants to Canada, 1971-1996," Annual meeting of the Canadian Population Society. Halifax.

Wright, Robert E. and Paul S. Maxim. 1993. "Immigration Policy and Immigrant Quality: Empirical Evidence from Canada," Journal of Population Economics 6: 337-52. 
Trends in the Occupational and Earnings Attainment

of Women Immigrants to Canada, 1971-1996

Appendix Table A1. Measurement of Variables

\section{Dependent Variables:}

1. Earnings: Natural Logarithm of gross wages and salaries from employment to the nearest dollar expressed in 1996 Canadian dollars.

2. Professional or Managerial Occupation: A dummy variable coded ' 1 ' if respondent is employed in a professional or managerial occupation, ' 0 ' otherwise. See text for details.

\section{Socioeconomic Characteristics:}

3. Years of Schooling. Measured by means of a "spline function" in which all schooling from zero to 12 or more years is coded separately from years of postsecondary schooling. Graded schooling is coded 1 to 11 for respondents whose highest level corresponds to those years and 12 for those who have twelve or more years of schooling. The postsecondary variable is coded 0 for those who never attended college or university and in increments of one unit for each year attended. Grade 13 is assigned to postsecondary.

4. Knowledge of Official Languages Coded ' 1 ' if the respondent cannot carry on a conversation in either official language, coded ' 0 ' if respondent can carry on a conversation in either official language.

5. Marital Status. A dummy variable coded ' 1 ' if respondent is married, ' 0 ' otherwise.

6. Number of Children: Coded as actual number of children ever born for 1971 and1981, number of children in household for 1986, 1991, and 1996.

7. Urban Residence: Coded ' 1 ' if respondent resides in a Census Metropolitan Area (CMA), '0' otherwise (for 1971 coded 1 if respondent resides in a place with more than 30,000 population).

8. Weeks Worked: Number of weeks during year prior to census during which respondent worked, even if only a few hours.

9. Part-Time Work: A dummy variable coded ' 1 ' if respondent worked mainly part-time during year prior to the census, ' 0 ' if mainly full-time. 
Richard A. Wanner and Michelle Ambrose

10. Educated in Canada. Respondents were classified as educated in Canada if they were either born in Canada or the age at which they arrived in Canada was less than the age at which they completed their schooling, estimated as number of years of schooling minus five. 